\title{
A Regional Agricultural Trade Model for Wheat and Sunflower Seeds in Ukraine
}

\author{
Alexander Kobzev
}

\section{Introduction}

Ukraine has a significant potential for agricultural production. The country enjoys a large area of agricultural land with fertile soils combined with favourable climatic conditions. All that creates the necessary environmental preconditions to cultivate many crops on a large-scale and to develop an efficient livestock production. A beneficial geographic location, and relative proximity to important markets such as the countries of the former Soviet Union and the Middle East allows Ukraine to export many agricultural commodities. And yet, agricultural production has been declining for the last decade. The agricultural output in Ukraine has decreased to almost one half of 1990 levels. Only in the last year has the situation been reversed and a slight increase in agricultural production was posted. Ineffective state agricultural policies together with excessive marketing costs have been two major reasons contributing to the decline in agricultural production.

For the last years, the Ukrainian government has repeatedly proclaimed its intention to join the world economic system and has even submitted an official application to the World Trade Organisation (WTO). However, to be fully integrated into the WTO and enjoy the advantages of membership, Ukraine must first liberalise its agricultural trade policies. Such liberalisation would apply not only to trade across external borders, but to internal trade as well. Free trade at the regional level provides for more efficient allocations of domestic resources, addresses the food security issue, and promotes the consolidation of domestic commodity markets.

The practice of the last years demonstrates than certain actions of the regional authorities in Ukraine create serious impediments to the efficiency of regional agricultural trade in Ukraine. The introduction of bans on the movement of agricultural commodities, in particular grain, between Ukrainian regions (oblasts) is a notorious example. In this situation, the losers are not only the local producers and traders, but the whole nation. Meanwhile, as the prospects for a better grain harvest in 2001 are growing, which may shift Ukraine from being a net-importer to an exporter of grain, so is the likelihood that the old practices of controlling regional commodity trade will be employed again.

In this context, the purpose of this paper is to demonstrate the negative consequences of certain state policies and established practices, and to analyse their implications both at the national and the regional levels. In section 2 the study employs a social welfare analysis and demonstrates the effects of excessive marketing costs on domestic price, on consumer and producer surpluses, and on social welfare. To simulate different state policies and practices on the wheat and sunflower seed markets in Ukraine, the author uses a GAMS model. The essentials of the model and the techniques for the calculation of regional wheat and sunflower supplies and demands as well as the regional elasticities are presented in section 3 .

The results of the main model scenarios and an analysis of the distortional effects of certain policies and practices are elaborated in section 4 . The study pays special attention to the changes in producer and consumer surpluses, transportation costs, and social welfare caused by high marketing costs, export taxes, and regional bans on the movement of agricultural commodities. The repercussions of such policies at the regional level are the prime focus of this section. The principal conclusions and policy implications are presented in section 5 .

\section{Excessive marketing costs and social welfare losses}

Despite the fact that Ukraine's agricultural potential greatly exceeds the present level of agricultural production, existing ineffective mechanisms and policies are major impediments to increasing production 
and social welfare in the country. Excessive marketing costs combined with an undeveloped infrastructure of the agrarian market are two of the prime reasons for the decline of the national agriculture.

To analyse the effects of different policy mechanisms and practices it is useful to employ the concepts of consumer and producer surpluses and of social welfare analysis. Social welfare analysis considers costs and benefits to different socio-economic groups as well as net social welfare losses or benefits (Colman and Young, 1994).

In a broad sense, excessive marketing costs include the transportation, storage and handling costs of agricultural commodities and the costs of certain government policies on the agricultural market. Excessive marketing costs have a negative effect on domestic prices and lead to a redistribution of economic wealth between various economic agents.

To demonstrate the negative effect of excessive marketing costs on domestic prices, producer and consumer surpluses and social welfare, a graphical analysis shall be employed. Graph 16.1 represents the agricultural trade of those commodities of which Ukraine is traditionally a net-exporter, i.e. wheat and sunflower seeds. Under free trade and given that Ukraine is a small country, i.e. it cannot influence the world market price significantly, the domestic price for a given agricultural commodity is directly linked to the world price. World prices for agricultural commodities determine Ukrainian domestic prices since in general Ukrainian farmers have the choice between exporting or selling their produce domestically.

It is reasonable to assume that if domestic prices are lower than world market prices, Ukrainian producers and traders will be encouraged to export maximum volumes of the produced output. In the opposite situation where internal prices are higher than world market prices, Ukrainian farmers will not export the commodity in question but will sell it domestically. Therefore, for agricultural producers the opportunity cost of selling a commodity domestically is always the world market price (von Cramon-Taubadel, 2000).

\section{Graph 16.1}

The effects of high marketing cost on the domestic price and on social welfare

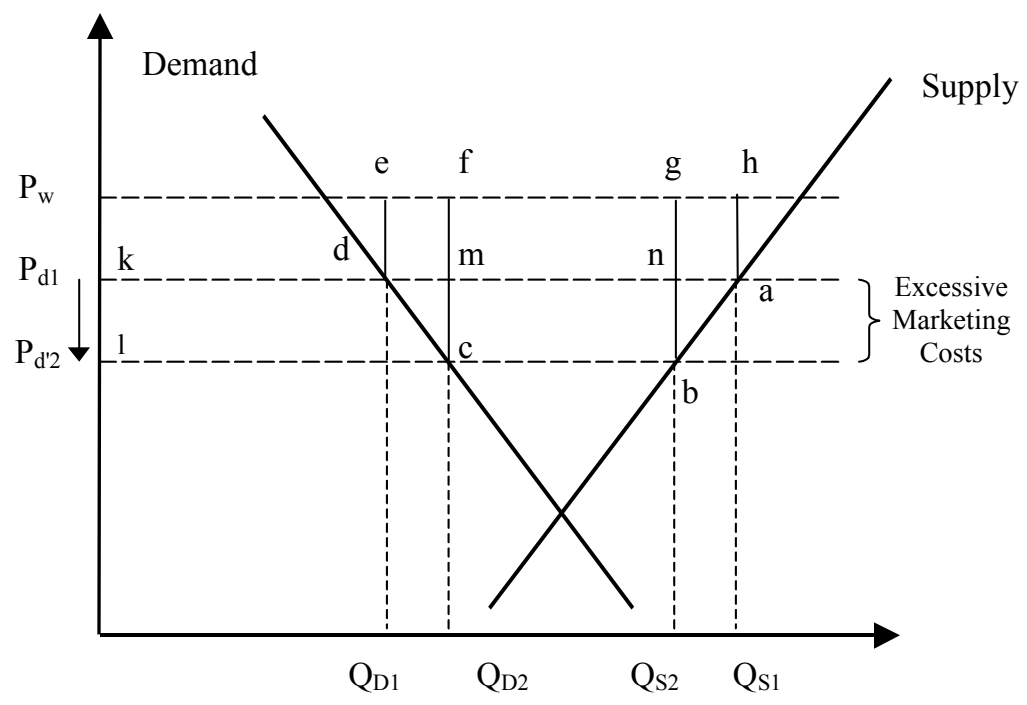

Source: own drawing

In an export situation, the price on the domestic market $\left(P_{d l}\right)$ equals the world price $\left(P_{w}\right)$ minus the costs for transportation and handling, as would be the case when marketing costs are relatively moderate and there are no interventions from the government. At the domestic price $P_{d l}$, producers supply the quantity $Q_{S I}$, out of which $\mathrm{O}_{\mathrm{D} 1}$ is consumed domestically and the difference (da) is exported.

Excessive marketing costs (unreasonably high transportation and handling costs combined with government intervention policies such as export tariffs and duties) depress the domestic price further, down to $P_{d 2}$. In this situation the difference between the two domestic prices $P_{d 1}$ and $P_{d 2}$ is a wedge caused by the excessive costs. As the domestic commodity price falls, supply is shifting from $\mathrm{Q}_{\mathrm{S} 1}$ to $\mathrm{Q}_{\mathrm{S} 2}$. The degree of supply decrease depends on a score of factors, and first of all, on supply elasticity. 
The reaction of consumers to this situation of a lower domestic price $\mathrm{P}_{\mathrm{d} 2}$ is the opposite. Now they can purchase the commodity at a lower price, which raises domestic consumption from $\mathrm{Q}_{\mathrm{D} 1}$ to $\mathrm{Q}_{\mathrm{D} 2}$. Thus, consumers and producers are affected differently in this situation. The lower price negatively effects local producers who receive lower revenues because of higher costs. The producer surplus is decreased by the area of $P_{d 1} a b P_{d 2}$. Meanwhile the consumer is better off: At the lower domestic price $P_{d 2}$ the consumer surplus is increased by the area $P_{d 1} d c P_{d 2}$. The higher marketing costs bring additional proceeds to commodity traders and to the state budget. Their revenue rose from the rectangle fgnm to the rectangle $f g b c$.

Analysing the losses and gains in the graph, one can see that the area of the total losses $(\mathrm{kabl})$ is larger than the areas of the total gains $(k d c l$ plus $m n b c)$. That means that the losses carried by producers outweigh the gains obtained by the consumers, the traders and the state. In this situation, the areas efcd and ghab represent the losses to society or the so-called social welfare losses. The figure ghab represents a net loss because $Q_{S 2} Q_{S 1}$ units could be sold at the price $P_{d l}$ but are not produced after the costs have risen. The figure efcd is the producer surplus loss because the quantity $Q_{D 1} Q_{D 2}$ is sold to domestic buyers at $P_{d 2}$ rather than to foreign buyers at $P_{d l}$.

Marketing costs in Ukraine include elevator storage and handling, railway costs, DAF rail handling and custom costs, seaport handling weight losses, certification, financial and transaction costs, as well as certain additional expenses. Besides that, storage costs include not only the physical costs of handling an agricultural commodity at the elevators but also the opportunity costs of the capital related to the commodity stocks and the costs of quality and quantity losses in storage (von Cramon-Taubadel, 2000).

Storage costs also include a risk premium, which reflects the traders' uncertainty regarding free access to the delivered commodities. Furthermore as of last year, the State Customs Service required special export certificates from the State Grain Inspectorate to certify the quality of the grain. These policies were officially introduced "in order to eliminate defects in export-import operations with grain and to increase state control". This year the Cabinet of Ministers intends to introduce mandatory insurance for all agricultural enterprises producing grain and sugar beets (Ukragroconsult, May 2001). Such levies increase marketing costs and contribute to the declining profitability of Ukrainian farms.

Also related to excessive marketing costs is the issue of extremely high losses of agricultural crops. Along with increasing yields the gross harvest is heavily dependent on decreasing losses at the time of harvesting, during transport, procuring, and storage. Average wheat losses amount to $40 \mathrm{~kg}$ per hectare and total direct losses caused by repeated loading and unloading, technical deficiencies and inadequate capacities of the grain cleaning and drying equipment could reach as much as $1 \mathrm{~m}$ tons annually (Balabanov, 1998). One of the main reasons for losses is poorly constructed and badly maintained harvesting machinery, as well as poor conditions of rolling stock, roads, and processing machinery. Thus, under conditions of stiff world market competition excessive marketing costs are weakening Ukraine's positions as an agricultural exporter.

\section{A regional agricultural trade model}

\subsection{Specifications of the model}

To model and simulate regional agricultural production and trade, the study utilises GAMS (General Algebraic Modelling System). ${ }^{1}$ It applies the Takayama and Judge Quadratic Programming approach with non-linear programming techniques.

Utilising existing data on marketing costs and state interventional policy instruments, the model mathematically formulates and optimises supply and demand of the agricultural commodity in question. It calculates the producer and consumer surpluses, agricultural commodity flows, and the domestic price both at the national and regional levels.

Marketing costs represent a set of exogenous variables introduced into the model. They include elevator storage and handling, railroad fees, DAF rail handling and custom costs, seaport handling, required

1 The author would like to express special gratitude to Sergiy Zorya and to the Institute of Agricultural Economics at the University of Göttingen for advice and help in developing and running the model used in this investigation. 
commodity certification, harvest, storage, and transportation losses, and some additional expenditures incurred by transaction costs. As the concept of marketing costs is being considered in a very broad sense, some instruments of state agricultural policies such as export duties and import tariffs are introduced into the model as well.

The model assesses the size of the losses to consumer and producer welfare due to excessive marketing costs and defines their distribution at the regional level. The regional specifications of the model allow determining which regions are winners and which ones are losers in this situation.

\subsection{Regional supply, demand, and elasticities}

At the initial stage of modelling, the author calculated regional supply and demand and determined regional elasticities for the commodities in question across all of Ukraine's oblasts. ${ }^{2}$

The supply of wheat and sunflower seeds was calculated on the basis of the commodity outputs in each oblast, subtracting losses. The total losses were distributed among oblasts in proportion to their harvested areas. Then the commodity opening stocks were added to the total regional supply.

Regional demand includes: produce (wheat, sunflower seeds) to be processed by the food industry, feed consumption, seed demand and commodity ending stocks. Regional food wheat consumption was calculated on the basis of each oblast's population. Regional oilseed consumption corresponds to the demand of the oil processing enterprises in the oblasts (Ukroliiaprom plants, large, middle, and small oil mills not affiliated with Ukroliiaprom). The regional seed demand was calculated on the basis of the wheat and sunflower seed sowing areas in each oblast. The regional feed demand corresponds to the oblast's share in Ukraine's livestock herd. For comparability, livestock units were converted into cattle with the following conversion coefficients: cattle $=1$, pig $=0.12$, and poultry $=0.01$.

To assess changes in consumer and producer behaviours caused by price fluctuations, short-term supply and demand elasticities were calculated. It has been assumed that the short-term supply elasticities are rather low since agricultural commodity price fluctuations in Ukraine do not cause immediate significant changes in outputs. The nation's farmers are not able to immediately re-allocate resources and change production plans. The availability of critical agricultural inputs rather than price expectations is likely to determine future outputs. For this reason, short-term supply elasticities of 0.1 to 0.2 were assigned to the commodities in question. It was also assumed that the larger the output (or the larger the oblast's share in total production), the higher the elasticity.

The short-term demand elasticities were estimated on the basis of regional consumption. The regional wheat demand elasticities were based on the number of livestock (feed wheat) and on the population (food wheat) in each oblast. The larger the livestock and the population, the higher the elasticity. The elasticities vary from 0.3 (Ivano-Frankivsk and Sumy oblasts) to 0.5 (Kyiv, Odesa and Dnipropetrovsk). In the case of sunflower seed demand elasticities, a higher demand from oil mills for inputs (Luhansk, Odesa and Dnipropetrovsk) defines higher elasticities.

\section{Model scenarios}

\subsection{Marketing cost reduction}

As already discussed in section 2, high marketing costs and state intervention policies are the main reasons for the redistribution of the wealth to the economic agents, which is distortional in its very nature. In a netexport situation, high costs represent an additional tax on agricultural producers. According to a study by the German Advisory Group, farmers in Ukraine obtain around $40 \%$ of the FOB price for grain and sunflower seeds, while farmers in Western Europe receive 70\% of this price (Striewe, 1998).

To demonstrate the distortional effect of excessive marketing costs, a number of simulations were run. For reasons of simplicity, all marketing costs but railroad fees were reduced by $50 \%$ and the railroad fees (set by Ukrzaliznytsia) were reduced by a third. The simulations show that at a wheat world price of $110 \mathrm{USD} / \mathrm{t}$

2 Ukragroconsult agricultural commodity data for the 2000/2001 and 2001/2002 marketing years were used. 
(FOB), the above reduction of marketing costs would lead to an increase in total social welfare by USD $64.5 \mathrm{~m}$. The total producer surplus rises from USD 4,002 m to USD 4,335 m, which is offset, because of the domestic price increase, by a decrease in consumer surplus of USD $268.9 \mathrm{~m}$. Thus, since the increase in producer surplus exceeds the reduction in consumer surplus, society as a whole would be better off.

The distribution of changes in producer and consumer surpluses for each region is presented in Table 16.1. The effect of eliminating excessive marketing costs is especially noticeable in the main wheat production areas of Odesa, Vinnycya, Kherson and Khmelnytsky oblasts. Producers in Odesa oblast alone would save USD $30.3 \mathrm{~m}$. Concerning changes in consumer welfare, the largest losses would be suffered in the most populated oblasts (Kyiv, Donetsk, Dnipropetrovsk and Luhansk) and the oblasts with the most developed livestock production (Lviv and Ternopil). They would now have to pay the higher domestic price of 87.1 $\mathrm{USD} / \mathrm{t}$, up from $68.2 \mathrm{USD} / \mathrm{t}$. It should also be noted that in many of these regions the changes in producer surplus would not offset those of the consumers'. Luhansk oblast is an example. The oblast is a net-loser by USD $7.3 \mathrm{~m}$. Thus, along with the negative redistribution effect, excessive marketing costs also cause a redistribution of social welfare across Ukrainian regions, i.e. lower domestic prices cause the main production oblasts to indirectly subsidise the oblasts with large volumes of consumption.

Table 16.1

Changes in producer and consumer surpluses due to postulated marketing cost reductions, in USD 1,000

\begin{tabular}{|c|c|c|c|c|}
\hline & \multicolumn{4}{|c|}{ Producer and consumer surpluses } \\
\hline & \multicolumn{2}{|c|}{$\begin{array}{l}\text { 2001/2002 marketing year } \\
\text { (export situation) }\end{array}$} & \multicolumn{2}{|c|}{$\begin{array}{l}\text { 2000/2001 marketing year } \\
\text { (import situation) }\end{array}$} \\
\hline & PS & CS & PS & $\mathrm{CS}$ \\
\hline Ukraine & 333,406 & $-268,938$ & $-40,536$ & 43,416 \\
\hline Crimea & 20,599 & $-11,984$ & $-2,500$ & 2,001 \\
\hline Vinnycya & 26,243 & $-13,815$ & $-3,231$ & 2,112 \\
\hline Volyn & 9,171 & $-7,754$ & $-1,139$ & 1,184 \\
\hline Dnipropetrovsk & 11,620 & $-14,811$ & $-1,385$ & 2,552 \\
\hline Donetsk & 5,145 & $-16,545$ & -605 & 2,909 \\
\hline Zhytomyr & 10,976 & $-10,544$ & $-1,358$ & 1,609 \\
\hline Zakarpattya & 1,381 & $-5,443$ & -168 & 900 \\
\hline Zaporizhya & 17,202 & $-11,042$ & $-2,083$ & 1,777 \\
\hline Ivano-Frankivsk & 3,936 & $-7,316$ & -487 & 1,174 \\
\hline Kyiv & 23,991 & $-18,328$ & $-2,959$ & 3,097 \\
\hline Kirovohrad & 16,343 & $-8,182$ & $-1,964$ & 1,275 \\
\hline Luhansk & 1,844 & $-9,188$ & -200 & 1,611 \\
\hline Lviv & 9,727 & $-13,416$ & $-1,202$ & 2,193 \\
\hline Mykolayiv & 16,804 & $-8,620$ & $-1,999$ & 1,362 \\
\hline Odesa & 30,340 & $-15,029$ & $-3,675$ & 2,427 \\
\hline Poltava & 8,858 & $-11,163$ & $-1,016$ & 1,761 \\
\hline Rivne & 8,234 & $-7,673$ & $-1,028$ & 1,185 \\
\hline Sumy & 10,706 & $-9,137$ & $-1,294$ & 1,426 \\
\hline Ternopil & 13,099 & $-8,714$ & $-1,622$ & 1,328 \\
\hline Kharkiv & 12,901 & $-14,451$ & $-1,519$ & 2,394 \\
\hline Kherson & 22,420 & $-9,063$ & $-2,698$ & 1,425 \\
\hline Khmelnytsky & 21,679 & $-11,776$ & $-2,723$ & 1,782 \\
\hline Cherkassy & 18,849 & $-10,642$ & $-2,314$ & 1,640 \\
\hline Chernivtsi & 3,658 & $-4,821$ & -449 & 782 \\
\hline Chernihiv & 7,680 & $-9,480$ & -918 & 1,510 \\
\hline
\end{tabular}

* The 2001/2002 marketing year data are an estimation based on Ukragroconsult agricultural commodity balances

Source: own calculations

It is worth mentioning that in the 2000/2001 marketing year when Ukraine was a net-importer of wheat, the situation concerning redistribution of consumer and producer surpluses presented the opposite picture. In that case, the elimination of excessive marketing costs would cause a decrease of the domestic price, which in turn would lead to a decrease of the producer surplus by USD $40.5 \mathrm{~m}$. However, the reduction of producer surplus would now be more than offset by the increase in consumer surplus, which means that social welfare would not suffer. 


\subsection{Government intervention policy simulations}

One of the most controversial agricultural policies implemented by the Ukrainian government remains the $23 \%$ sunflower seed export duty. The duty is a good example of a distortional policy instrument effecting production, consumption, trade, and income redistribution of several economic agents. The introduction of the duty has impaired the position of Ukraine as one of the main sunflower seed exporters and provoked a conflict situation with international financial institutions such as the IMF. Furthermore, the practice of the last years shows that the duty is unlikely to achieve some of its goals, such as to increase state revenues. Today a significant portion of sunflower seed exports is realised through a tolling scheme, which allows traders to avoid paying the duty fees.

In order to describe the possible economic impact of the duty, two scenarios were considered, one corresponding to cancellation of the export duty altogether, and another to reduce the duty down to $10 \%{ }^{3}$

The duty leads to a reallocation of profits on the oilseed market to the advantage of state revenues and also to processing enterprises. At the same time, the duty reduces the value of the sunflower seed production and causes financial losses to farmers. The model simulations show that in the 2001/2002 marketing year at a world price of $180 \mathrm{USD} / \mathrm{t}$ (FOB), the losses to producers could amount to as much as USD $158.2 \mathrm{~m}$ (the marketing costs remaining constant). In the case of a cancellation of the duty, total producer surplus would increase from USD $2,164 \mathrm{~m}$ to USD $2,416 \mathrm{~m}$.

The duty not only puts an excessive burden on agricultural producers, but together with excessive marketing costs depresses the domestic price to $97 \mathrm{USD} / \mathrm{t}$. This reduced domestic price can be considered as indirect subsidy to the oil processing industry represented mostly by Ukroliiaprom, which accounts for about two-third of the processed sunflower seeds. If the duty would be cancelled, oil mills would have to buy oilseeds at a higher price, which would rise to $121 \mathrm{USD} / \mathrm{t}$. In this situation, the consumer surplus of oilseeds would reduce from USD $266.4 \mathrm{~m}$ to USD $171.4 \mathrm{~m}$.

The introduction of the export duty has a distinct negative effect on the Ukrainian economy. It reduces the total social welfare. The farmers' losses are higher than the gains to the oil processing industry even when combined with the value of the revenue obtained from the export duty fees. As a result, the total welfare losses constitute USD $63.1 \mathrm{~m}$.

As a compromise to the present situation, the model considers the reduction of the export duty down to $10 \%$. Such a motion was proposed by the Ukrainian government in March 2001, but failed to pass Parliament. The reduction would increase the total producer surplus from USD $969.6 \mathrm{~m}$ to USD $1,057 \mathrm{~m}$, which eventually would raise the national net welfare by USD $31.8 \mathrm{~m}$.

Table 16.2

Changes in regional producer and consumer surpluses due to postulated changes of the sunflower export duty in the 2001/2002 marketing year, in USD 1,000

\begin{tabular}{|c|c|c|c|c|}
\hline & \multicolumn{4}{|c|}{ Producer and consumer surplus changes* } \\
\hline & \multicolumn{2}{|c|}{ Export duty cancellation } & \multicolumn{2}{|c|}{$10 \%$ export duty } \\
\hline & PS & $\mathrm{CS}$ & PS & CS \\
\hline Ukraine & 158,044 & $-94,950$ & 87,791 & $-56,365$ \\
\hline Crimea & 1,733 & -453 & 961 & -264 \\
\hline Vinnycya & 3,085 & $-3,127$ & 1,712 & $-1,841$ \\
\hline Dnipropetrovsk & 20,933 & $-11,602$ & 11,613 & $-6,914$ \\
\hline Donetsk & 20,734 & $-7,396$ & 11,605 & $-4,416$ \\
\hline Zakarpattya & 54 & -64 & 30 & -37 \\
\hline Zaporizhya & 20,357 & $-20,249$ & 11,291 & $-12,077$ \\
\hline Kyiv & 1,164 & $-1,187$ & 646 & -708 \\
\hline Kirovohrad & 13,907 & $-9,624$ & 7,719 & $-5,664$ \\
\hline Luhansk & 10,888 & $-5,259$ & 6,035 & $-3,142$ \\
\hline Lviv & 1 & -751 & 1 & -444 \\
\hline Mykolayiv & 11,456 & -302 & 6,359 & -180 \\
\hline Odesa & 14,164 & $-10,506$ & 7,866 & $-6,241$ \\
\hline Poltava & 9,222 & $-3,622$ & 5,117 & $-2,110$ \\
\hline Sumy & 1,857 & -57 & 1,030 & -33 \\
\hline Kharkiv & 15,652 & $-16,320$ & 8,681 & $-9,731$ \\
\hline Kherson & 7,124 & $-2,582$ & 3,953 & $-1,489$ \\
\hline
\end{tabular}

3 The effect of the tolling scheme on exports was not considered in the scenarios being discussed. 


\begin{tabular}{lrrrr} 
Khmelnytskyi & 124 & -6 & 69 & -3 \\
Cherkassy & 4,914 & -111 & 2,725 & -64 \\
Chernivtsi & 274 & $-1,116$ & 153 & -651 \\
Chernihiv & 301 & -611 & 168 & -356 \\
\hline
\end{tabular}

* The 2001/2002 marketing year data is an estimation based on Ukragroconsult agricultural commodity balances

Source: own calculations

The redistribution of producer and consumer surpluses at the regional level is presented in Table 16.2. The table clearly shows that the main oilseed producing oblasts - Donetsk, Dripropetrovsk, Zaporizhya, Kharkiv, Odesa and Kirovohrad -currently bear the highest losses. These oblasts, actually, subsidise a lower domestic price for the processing enterprises in the rest of the country. In this situation, the regions with large capacities to process sunflower seeds are definitely better off. This is also the case with the oblasts not producing sunflower seeds, but which have margarine and mayonnaise producing plants (Lviv, Chernihiv and Chernivtsi).

\subsection{Regional commodity movement ban simulations}

For the last years, a number of Ukraine's oblasts have repeatedly introduced bans on the regional movement of certain agricultural commodities, in particular so-called grain bans. Such actions are completely incompatible with the principles of a market economy and lead to substantial reductions in national welfare.

To demonstrate the negative economic effects of such intervention policies we simulated the introduction of a regional ban in the central part of Ukraine, namely Vinnycya oblast. It was assumed that the ban would only lead to an increase in transportation costs. To avoid Vinnycya oblast, the adjacent oblasts would have to use longer and more costly routes to trade their output.

Table 16.3

Producer and consumers surplus changes due to the introduction of a postulated ban on grain movement in central Ukraine (Vinnycya oblast) in the 2001/2002 marketing year; in USD 1,000

\begin{tabular}{lcc}
\hline & \multicolumn{2}{c}{ Surplus changes } \\
\cline { 2 - 3 } & PS & CS \\
\hline Ukraine & $-141,901$ & 124,439 \\
Vinnycya & $-112,278$ & 94,220 \\
Volyn & $-2,265$ & 2,062 \\
Zhytomyr & $-2,66$ & 2,741 \\
Zakarpattya & -571 & 2,446 \\
Ivano-Frankivsk & $-1,815$ & 3,671 \\
Kyiv & $-2,002$ & 1,702 \\
Lviv & $-2,417$ & 3,662 \\
Rivne & $-2,026$ & 2,029 \\
Ternopil & $-5,091$ & 3,672 \\
Khmelnytsky & $-8,377$ & 5,014 \\
Cherkassy & -357 & 220 \\
Chernivtsi & $-2,040$ & 3,001 \\
\hline
\end{tabular}

* The 2001/2002 marketing year data is an estimation based on Ukragroconsult agricultural commodity balances

Source: own calculations

As can be seen from Table 16.3, the introduction of a regional oblast ban has the following effects:

- due to a lower domestic price the producer surplus is reduced by USD $141.9 \mathrm{~m}$, while the consumer surplus goes up by USD 124.4;

- changes in consumer and producer surpluses would occur in twelve oblasts. The producers of Vinnycya oblast would experience the highest losses amounting to USD $112.3 \mathrm{~m}$, since now they could now trade their grain only within the oblast's borders, leading to a domestic price decrease of 35 $\mathrm{USD} / \mathrm{t}$;

- $\quad$ the oblasts of the central and western part of Ukraine such Khmelnytsky, Ternopil and Kyiv, which are large grain producers would suffer the most. At the same time, the southern and eastern oblasts would 
not experience any changes in producer and consumer surplus. They can pass around Vinnycya oblast and could increase their exports;

- the total social losses resulting from the postulated regional ban policy would amount to USD $17.5 \mathrm{~m}$. Thus, the introduction of a regional ban even in only one of Ukraine's oblasts would result in the redistribution of producer and consumer surpluses in many other regions of the nation. The reduction in producer surplus does not offset the increase in consumer surplus, leading to a substantial reduction in national welfare.

\section{Conclusions}

Excessive marketing costs and certain ineffective instruments of state agricultural policy negatively impact domestic agricultural production and cause distortional effects both at the national and regional levels. They lead to a redistribution of economic wealth between various economic agents and cause losses in total social welfare. Although Ukraine's agricultural potential greatly exceeds the present level of agricultural production, the described ineffective mechanisms and policies remain a bottleneck for agricultural reform in Ukraine.

The simulations of the agricultural regional model produced the following results:

1. For the 2001/2002 marketing year, the reduction of excessive marketing costs in wheat production would have lead to an increase in total social welfare by USD $64.5 \mathrm{~m}$. The producer surplus would have risen from USD 4,002 m to USD 4,335 m, partially offset by a consumer surplus decrease of USD $268.9 \mathrm{~m}$. This means that the society as a whole would have been better off.

2. The export duty on sunflower seeds represents another distortional instrument of agricultural policy. The duty leads to a reallocation of profits on the oilseed market to the advantage of state revenues and of processing enterprises. At the same time, the duty reduces the value of the sunflower seed production and causes financial losses to farmers. In the 2001/2002 marketing year the duty inflicted losses on producers amounting to USD $158.2 \mathrm{~m}$. Had the duty been cancelled, the total producer surplus would have increased from USD 2,164 m to USD 2,416 m, and the total welfare gains would have constituted USD $63.1 \mathrm{~m}$.

3. Along with the negative redistribution effect at the national level, the excessive marketing costs and the export duty cause a redistribution of social welfare across the regions. Due to lower domestic prices the main production oblasts implicitly subsidise the oblasts with large volumes of consumption. The elimination of excessive marketing costs would lead to a considerable increase in social welfare in the main wheat production areas of Odesa, Vinnycya, Kherson and Khmelnytsky oblasts. This is true also for the main sunflower seed producing areas, i.e. the Donetsk, Dripropetrovsk, Zaporizhya, Kharkiv and Odesa oblasts. With a lower domestic price these oblasts subsidise the oil processing enterprises in the rest of the country.

4. The practice of regional bans on the movement of agricultural commodities creates a serious impediments to the efficiency of regional agricultural trade in Ukraine. The introduction of a regional ban even in only one of Ukraine's oblasts results in the redistribution of producer and consumer surpluses in many other regions of the nation. The reduction in producer surplus exceeds the increase in consumer surplus, leading to substantial losses to national welfare as a whole.

\section{References}

Balabanov, G. (1998): The Geographical Segmentation of the Grain Sector in Ukraine. CPER Occasional Papers.

Colman, D. and Y. Trevor (1993): Principles of Agricultural Economics: Markets and Prices in Less Developed Countries. Cambridge University Press.

Striewe, L. (1998): Grain and Oil Marketing and Transportaion in Ukraine. German Advisory Group, Ukraine.

Ukragroconsult, weekly issues for 2000-2001.

von Cramon-Taubadel, S. (2000): After Decree N 832: Grain Market Policy in Ukraine, unpublished. 
